\title{
Auxological and hormonal prognostic factors of growth hormone (GH) therapy effectiveness in children with GH deficiency, available before treatment
}

\section{Wskaźniki auksologiczne $\mathrm{i}$ wyniki badań hormonalnych wykonanych przed rozpoczęciem terapii, warunkujące skuteczność leczenia hormonem wzrostu dzieci z somatotropinową niedoczynnością przysadki}

\author{
1,2Joanna Smyczyńska, 1,2Renata Stawerska, ${ }^{2,3}$ Andrzej Lewiński, ${ }^{1,2}$ Maciej Hilczer
}

${ }^{1}$ Department of Pediatric Endocrinology, Medical University of Lodz, ${ }^{2}$ Department of Endocrinology and Metabolic Diseases, Polish Mother's Memorial Hospital - Research Institute in Lodz, ${ }^{3}$ Department of Endocrinology and Metabolic Diseases Medical University of Lodz, Poland

Adres do korespondencji:

Joanna Smyczyńska, Klinika Endokrynologii i Chorób Metabolicznych Instytutu Centrum Zdrowia Matki Polki w Łodzi, 93-338 Łódź, ul. Rzgowska 281/289, tel.: +48 4227117 15; fax: +48 4227113 43; e-mail: joanna.smyczynska@neostrada.pl

Key words: short stature, growth hormone deficiency, growth hormone therapy, insulin-like growth factor-l, final height, target height, predicted adult height Słowa kluczowe: niedobór wzrostu, somatotropinowa niedoczynność przysadki, leczenie hormonem wzrostu, insulinopodobny czynnik wzrostowy-l, wzrost końcowy, wzrost docelowy, wzrost przewidywany

\section{ABSTRACT/STRESZCZENIE}

Background. The prognostic factors of growth hormone (GH) therapy effectiveness in children with GH deficiency (GHD) are still a matter of discussion. Aim. Assessment of the relationships between GH therapy effectiveness and the results of selected auxological and hormonal tests, available before treatment in children with isolated, non-acquired GHD. Subjects and methods. The analysis comprised 150 patients with isolated, non-acquired GHD, who completed $\mathrm{GH}$ therapy and reached final height (FH). In all the patients, selected auxological indices and IGF-I concentration were assessed before treatment. Effectiveness of GH therapy was compared with respect to patients' sex, pubertal development, severity of deficit of height, GH peak in stimulating tests and IGF-I secretion before treatment. Results. There was no difference in GH therapy effectiveness between boys and girls and between prepubertal and pubertal children. There was also no difference in FH with respect to the severity of GHD. Better improvement of FH was observed in the patients with more severe deficit of height, as well as in ones with lower IGF-I secretion. The effectiveness of GH therapy in the patients with high IGF-I level before treatment was poor. Conclusion. The severity of the deficit of height and of IGF-I deficiency but not the results of GH stimulating tests are the important prognostic factors of GH therapy effectiveness in children with isolated, non-acquired GHD. Pediatr. Endocrinol. 12/2013;2(43):9-20. 
Wstęp. Czynniki prognostyczne warunkujące skuteczność terapii hormonem wzrostu (GH) dzieci z somatotropinową niedoczynnością przysadki (GHD) są nadal przedmiotem badań. Cel pracy. Oceniano zależność pomiędzy skutecznością terapii GH a wybranymi wskaźnikami auksologicznymi i wynikami badań hormonalnych wykonanych przed rozpoczęciem leczenia u dzieci z izolowanym, nienabytym GHD. Pacjenci i metody. Analizą objęto dane 150 pacjentów z izolowanym, nienabytym GHD, którzy ukończyli terapię GH i osiągnęli wzrost końcowy (FH). U wszystkich pacjentów przed rozpoczęciem leczenia oceniono wybrane wskaźniki auksologiczne oraz dokonano pomiaru stężenia IGF-I. Skuteczność terapii oceniono w odniesieniu do płci, stadium dojrzewania, ciężkości niedoboru wzrostu, wydzielania GH w testach stymulacyjnych i stężenia IGF-I przed rozpoczęciem leczenia. Wyniki. Nie stwierdzono różnic w skuteczności terapii GH u dziewcząt i chłopców, jak również pomiędzy dziećmi w okresie przeddojrzewaniowym i z rozpoczętym dojrzewaniem płciowym. Uzyskany FH nie różnił się także w zależności od ciężkości GHD. Skuteczność terapii była większa u pacjentów z cięższym niedoborem wzrostu oraz z niższym wydzielaniem IGF-I przed leczeniem. Leczenie okazało się nieskuteczne u pacjentów z wysokimi stężeniami IGF-I przed jego rozpoczęciem. Wniosek. Ciężkość niedoboru wzrostu oraz ciężkość wtórnego niedoboru IGF-I przed leczeniem GH okazały się istotnymi czynnikami prognostycznymi skuteczności terapii, podczas gdy nie wykazano zależności efektów leczenia od wydzielania GH w testach stymulacyjnych. Endokrynol. Ped. 12/2013;2(43):9-20.

\section{Introduction}

The most important goal of growth hormone (GH) therapy in short children with GH deficiency (GHD) is improvement of height velocity (HV) and achievement of normal final height (FH). Even though currently most of the children treated with $\mathrm{GH}$ reach normal $\mathrm{FH}$, their mean adult height is about 1.0 SD below the mean value for reference population and $15-20 \%$ of all the treated patients remain short [1].

The reports on $\mathrm{FH}$ of the patients with childhood-onset GHD, treated with GH up to FH indicate a tendency to treat the patients with less severe deficit of height and to use higher doses of GH [1]. The liberalisation of the cut-off level of GH peak in GH stimulating tests (GHST), confirming GHD (from $5 \mathrm{ng} / \mathrm{ml}$ to $10 \mathrm{ng} / \mathrm{ml}$ ) has resulted in an increased number of treated patients, who - in majority - reach normal FH, however the decrease of the mean height gain during the therapy is observed [2]. The importance of other factors, determining FH, is still a matter of discussion. From the practical point of view, it seems particularly important to focus on the data available before the therapy onset. Such approach could be a contribution to optimisation the criteria of subjecting short children to GH therapy.

Insulin-like growth factor-I (IGF-I) is the main peripheral mediator of $\mathrm{GH}$ action. The main pool of IGF-I is synthesised in the liver, under control of $\mathrm{GH}$, however the decreased GH sensitivity, as well as the impaired ability to IGF-I synthesis (despite normal GH secretion) should be considered. Even so - in general - IGF-I plasma concentration reflects $\mathrm{GH}$ secretion, being relatively stable, in contrast to highly variable GH levels [3]. In 1996,
Rasat et al. [4] proposed to introduce an assessment of IGF-I and its binding protein-3 (IGFBP-3) plasma concentrations as a simple screening procedure in diagnosing GHD in short children. According to their suggestions, GHST should be performed only in the patients with decreased IGF-I secretion. However, in 2000 GH Research Society [5] still recommended GHST as the standard procedure in diagnosing GHD, however pointing at its limitations. The arbitrarily established cut-off levels for GHST, as well as the poor reproducibility of their results, reported in 1995 by Rosenfeld et al. [2], seem to be the problems not to overcome. The proposal of IGF-I assessment in the initial phase of diagnosing GHD was then repeated in some papers $[6,7]$. Moreover, in recent years GHD has been defined as secondary IGF-I deficiency $[8,9]$. In Poland, IGF-I assessment before GH therapy administration is obligatory but decreased IGF-I secretion is not a criterion of subjecting a patient to $\mathrm{GH}$ therapy [10]. Thus, up to now, it is possible to qualify children with either normal or even high IGF-I secretion as GH-deficient.

The aim of current study has been to assess the relationships between the growth-promoting effects of GH therapy and the results of selected auxological and hormonal examinations, performed before the therapy onset.

\section{Patients and methods}

The analysis comprised 150 children (115 boys, 35 girls), age at therapy onset $12.2 \pm 2.3$ years (mean $\pm \mathrm{SD}$ ) with short stature, related to disorders of either GH secretion or its bioactivity, who started GH therapy in 1997-2001 and completed it at the 
attainment of FH. Before GH administration, the following examinations were performed in all the patients:

1. Measurement of height of the patients and their parents, followed by the calculation of patients' height SDS ( $\left.\mathrm{H}_{0} \mathrm{SDS}\right)$, target height $(\mathrm{TH})$ and TH SDS, as well as - so called - „corrected” $\mathrm{H}_{0} \mathrm{SDS}$, according to the formula: $\operatorname{corrH}_{0} \mathrm{SDS}=$ $\mathrm{H}_{0} \mathrm{SDS}-\mathrm{TH}$ SDS. Short stature was defined as patient's height below $3^{\text {rd }}$ centile for age and sex. Reference data for Polish children [11] were used, assuming an exact value of -1.88 for height SDS (HSDS) as an equivalent to $3^{\text {rd }}$ centile.

Additionally, according to the deficit of height with respect to parental height, all the patients were classified as either fulfilling the criteria of familial short stature (FSS) or not (nonFSS). For every child, the cut-off value of HSDS for FSS and non-FSS was calculated, according to Ranke [12] and the children with $\mathrm{H}_{0}$ SDS below the cutoff value were classified as non-FSS, while the remaining ones - as FSS.

2. Pubertal stage was assessed according to Tanner's scale and all the patients were qualified at therapy onset as either prepubertal or pubertal.

3. Growth hormone secretion was assessed in two standard GHST - with clonidine $(0.15 \mathrm{mg} /$ $\mathrm{m}^{2}$, orally) and with either insulin $(0.1 \mathrm{IU} / \mathrm{kg}, i . v$. $)$ or glucagon $(30 \mu \mathrm{g} / \mathrm{kg}, i . m$. $)$. GH peak below 10 $\mathrm{ng} / \mathrm{ml}$ in both tests confirmed GHD. Severe GHD (sGHD) was diagnosed when GH peak was below $5 \mathrm{ng} / \mathrm{ml}$ in both tests, partial GHD (pGHD) for GH peak between 5 and $10 \mathrm{ng} / \mathrm{ml}$. In 22 patients with previously normal GH response to stimulation, the decreased GH secretion was observed in the repeated GHST, performed due to slow HV during the observation and decreased IGF-I level in at least two assessments (thus enabling subjecting them to GH therapy as fulfilling the criteria of GHD). These patients, with "verified" diagnosis, were qualified to a separate group (verifGHD). Blood samples for $\mathrm{GH}$ estimation were collected every $30 \mathrm{~min}$ (from 0 to $120 \mathrm{~min}$ ) in clonidine and insulin tests, and at 0 , $90,120,150,180 \mathrm{~min}$ in the test with glucagon. The concentration of GH was measured by the two-site chemiluminescent enzyme immunometric assay (hGH IMMULITE, DPC).

4. In all the patients, basal serum IGF-I and IGFBP-3 concentrations were measured in the blood samples collected before the first of GHST, fasting, at morning hours. Both IGF-I and IGFBP3 concentrations were assessed by a solid-phase, enzyme-labelled chemiluminescent immunometric assays, (IMMULITE, DPC). For comparison among the children with different age and sex, IGF-I concentrations were expressed as IGF-I SDS. For calculation of the IGF-I/IGFBP-3 molar ratio, the following molecular masses were used: $7.5 \mathrm{kDa}$ for IGF-I and $42.0 \mathrm{kDa}$ for IGFBP-3. It should be stressed that - according to the assumed criteria - children with decreased GH response to pharmacological stimulation were qualified to GH therapy, independently from either decreased or normal IGF-I secretion.

5. Bone age (BA) was assessed according to Greulich-Pyle's standards [13] and predicted adult height $(\mathrm{PAH})$ was calculated for each patient at therapy onset, according to Bayley-Pinneau's method [14].

6. In each patient, magnetic resonance imaging of the hypothalamic-pituitary region was performed and the children with any detectable abnormalities (except for anterior pituitary hypoplasia), as well as ones with acquired GHD, were excluded from the study. Other exclusion criteria encompassed any chronic diseases, congenital defects of internal organs, dysmorphic features and diagnosed or even suspected genetic syndromes (Turner syndrome was excluded in every girl by the karyotype assessment). In every patient included to the study, thyroid function was normal and there were no data suggesting other pituitary hormone deficiencies than GHD or other hormonal disorders.

The therapy with GH in the mean dose of $0.19 \pm 0.06 \mathrm{mg}(0.57 \pm 0.06 \mathrm{IU}) / \mathrm{kg} /$ week was administered up to the moment of fulfilling the criteria of its completion, i.e., when either bone epiphyses were closed or height velocity in terms of treatment decreased below $2 \mathrm{~cm} /$ year.

After completion of linear growth, patients' FH was measured and its centile position was assessed, followed by calculation of FH SDS and "corrected" FH SDS (according to the formula: corrFH SDS = FH SDS - TH SDS). Additionally, the change of FH SDS vs. $\mathrm{H}_{0} \mathrm{SDS},(\Delta \mathrm{HSDS})$ was calculated.

The effectiveness of GH therapy was analysed with respect to the following criteria:

- patient's sex (boys vs. girls) and pubertal stage at therapy onset (prepubertal vs. pubertal children),

- the relative deficit of height with respect to parental height (FSS vs nonFSS),

- GH peak in GHST (sGHD vs. pGHD, vs. verifGHD), 
- IGF-I secretion before treatment: low - below $10^{\text {th }}$ centile (IGI-I SDS below -1.29), normal - between $10^{\text {th }}$ and $90^{\text {th }}$ centile (IGF-I SDS from -1.29 to +1.29 ) or high - over $90^{\text {th }}$ centile (IGF-I SDS over +1.29).

Statistical analysis included non-parametric tests: Mann-Whitney's U test and Kruskall-Wallis' test for independent samples for the assessment of differences among the groups in particular time points.

The study was approved by the local Ethics Committee.

\section{Results}

\section{Effectiveness of GH therapy in boys and girls}

At therapy onset, girls were significantly younger than boys, while the therapy duration was insignificantly longer in girls. There was no difference in any of the assessed auxological parameters and in GH peak in GHST between boys and girls at therapy onset, while IGF-I concentrations presented significantly lower in boys. Despite older age at therapy onset and shorter mean duration of treatment, both the improvement of height SDS ( $\triangle$ FHSDS vs $\mathrm{H}_{0} \mathrm{SDS}$ ) and the obtained FH SDS was significantly better in boys than in girls. There was no significant difference both in PAH before treatment and in the obtained FH with respect to PAH. The detailed data are presented in Table I.

\section{Effectiveness of GH therapy in prepubertal and pubertal children}

Children who entered puberty before treatment presented with more severe deficit of height at therapy onset than prepubertal ones, however the difference between them was insignificant. There was also no significant difference in GH secretion, while pubertal children had higher IGF-I SDS than prepubertal ones. Despite considerably shorter therapy duration, the improvement of HSDS was significantly better in the patients who were pubertal at therapy onset, however the difference in $\mathrm{FH}$ was insignificant. Independently from pubertal stage at therapy onset, FH was slightly better than PAH but lower than TH in both Groups and the obtained

Table I. Selected auxological and hormonal data of boys and girls at therapy onset and at the attainment of $\mathrm{FH}$ Tabela I. Wybrane dane auksologiczne i wyniki badań hormonalnych u dziewcząt i chłopców przed rozpoczęciem terapii GH i po uzyskaniu FH

\begin{tabular}{|l|c|c|c|}
\hline Group & boys & girls & $p$ \\
\hline Before treatment (at therapy onset) & 115 & 35 & \\
№ of patients & $12.8 \pm 2.8$ & $10.1 \pm 2.5$ & $<0.0001$ \\
Age (years) & $-2.25 \pm 0.65$ & $-2.17 \pm 0.45$ & 1.00 \\
H S SDS & $-0.64 \pm 0.83$ & $-0.61 \pm 0.76$ & 0.92 \\
TH SDS & $-1.63 \pm 0.92$ & $-1.58 \pm 0.83$ & 0.98 \\
corrH SDS & $-1.06 \pm 1.11$ & $-1.24 \pm 0.98$ & 0.37 \\
PAH SDS & $7.6 \pm 4.2$ & $7.7 \pm 2.2$ & 0.22 \\
GH peak (ng/mL) & $-0.64 \pm 1.36$ & $-0.06 \pm 1.81$ & 0.001 \\
IGF-I SDS & & & \\
After treatment (at the attainment of FH) & $4.8 \pm 3.0$ & $5.4 \pm 2.5$ & 0.12 \\
Therapy duration (years) & $-0.89 \pm 0.85$ & $-1.17 \pm 0.82$ & 0.05 \\
FH SDS & $-0.28 \pm 1.02$ & $-0.56 \pm 0.87$ & 0.08 \\
CorrFH SDS & $1.36 \pm 0.79$ & $0.95 \pm 0.78$ & 0.01 \\
$\triangle$ FHSDS vs HoSDS & $0.15 \pm 0.91$ & $0.02 \pm 1.13$ & 0.76 \\
\hline FHSDS vs PAH SDS & & & \\
\hline
\end{tabular}


corrFH presented very similar in them. The detailed data are presented in Table II.

\section{Effectiveness of GH therapy in the patients with FSS and nonFSS}

Before treatment, the patients with nonFSS had significantly more severe deficit of height than ones with FSS $(p<0.0001)$, despite taller parents (i.e. higher TH SDS). It seems worth to be noticed that GH and IGF-I secretion before the therapy presented similar in both Groups. Due to significantly higher $\triangle$ HSDS in nonFSS than in FSS $(\mathrm{p}<0.0001)$, the obtained FH, expressed as FH SDS was very similar in both Groups. However, while corrected with respect to $\mathrm{TH}$, corrFH SDS presented significantly $(p<0.01)$ worse in nonFSS than in FSS. Interestingly, FH corresponded to TH in FSS, while in nonFSS the obtained obtained FH SDS was significantly lower than TH SDS $(\mathrm{p}<0.05)$. In both Groups, the difference in PAH and the relationship between FH and PAH was similar. The detailed data are presented in Table III.
Effectiveness of GH therapy in the patients with $s G H D, p G H D$ and verifGHD

Despite different results of GHST, there was no difference in any of the assessed auxological indices among the Groups, both before treatment and at FH. Interestingly, IGF-I secretion was significantly lower in verifGHD than in both sGHD and pGHD Groups $(\mathrm{p}=0.03)$, despite simultaneously obtained normal GH peak in GHST (during first assessment). The detailed data are presented in the Table IV (for verifGHD Group the higher values of GH peak, obtained during the first of two assessments are shown).

Effectiveness of GH therapy in the patients with respect to IGF-I secretion before treatment

There was no significant difference in $\mathrm{H}_{0} \mathrm{SDS}$ among the Groups with either decreased or normal, or high IGF-I secretion before treatment. However, in the Group with high IGF-I levels, TH presented significantly lower while corrH $\mathrm{H}_{0} \mathrm{SDS}$ - significantly higher than in other Groups. Namely, despite the

Table II. Selected auxological and hormonal data at therapy onset and at the attainment of FH in children who started GH therapy as either prepubertal or pubertal

Tabela II. Wybrane dane auksologiczne i wyniki badań hormonalnych przed rozpoczęciem terapii GH i po uzyskaniu FH u dzieci rozpoczynających leczenie w okresie przeddojrzewaniowym lub w okresie dojrzewania płciowego

\begin{tabular}{|c|c|c|c|}
\hline Group & prepubertal & pubertal & $\mathrm{p}$ \\
\hline \multicolumn{4}{|c|}{ Before treatment (at therapy onset) } \\
\hline № of patients & 86 & 64 & \\
\hline Age (years) & $10.9 \pm 2.9$ & $14.1 \pm 1.6$ & $<0.0001$ \\
\hline $\mathrm{H}_{0} \mathrm{SDS}$ & $-2.19 \pm 1.56$ & $-2.29 \pm 0.65$ & 0.29 \\
\hline TH SDS & $-0.72 \pm 0.87$ & $-0.51 \pm 0.72$ & 0.16 \\
\hline CorrH $_{0}$ SDS & $-1.48 \pm 0.90$ & $-1.79 \pm 0.87$ & 0.07 \\
\hline PAH SDS & $-1.24 \pm 0.99$ & $-0.95 \pm 1.16$ & 0.18 \\
\hline GH peak (ng/mL) & $7.9 \pm 4.2$ & $7.3 \pm 3.4$ & 0.44 \\
\hline IGF-I SDS & $-0.71 \pm 1.56$ & $-0.22 \pm 1.35$ & 0.04 \\
\hline \multicolumn{4}{|c|}{ After treatment (at the attainment of $\mathrm{FH}$ ) } \\
\hline Therapy duration (years) & $6.1 \pm 2.7$ & $3.2 \pm 2.2$ & $<0.0001$ \\
\hline FH SDS & $-1.04 \pm 0.83$ & $-0.85 \pm 0.86$ & 0.13 \\
\hline corrFH SDS & $-0.35 \pm 1.01$ & $-0.33 \pm 0.97$ & 0.71 \\
\hline$\Delta \mathrm{FHSDS} v s \mathrm{H}_{0} \mathrm{SDS}$ & $1.15 \pm 0.79$ & $1.41 \pm 0.80$ & 0.01 \\
\hline$\Delta$ FHSDS vs PAH SDS & $0.13 \pm 0.1 .01$ & $0.10 \pm 1.13$ & 0.85 \\
\hline
\end{tabular}




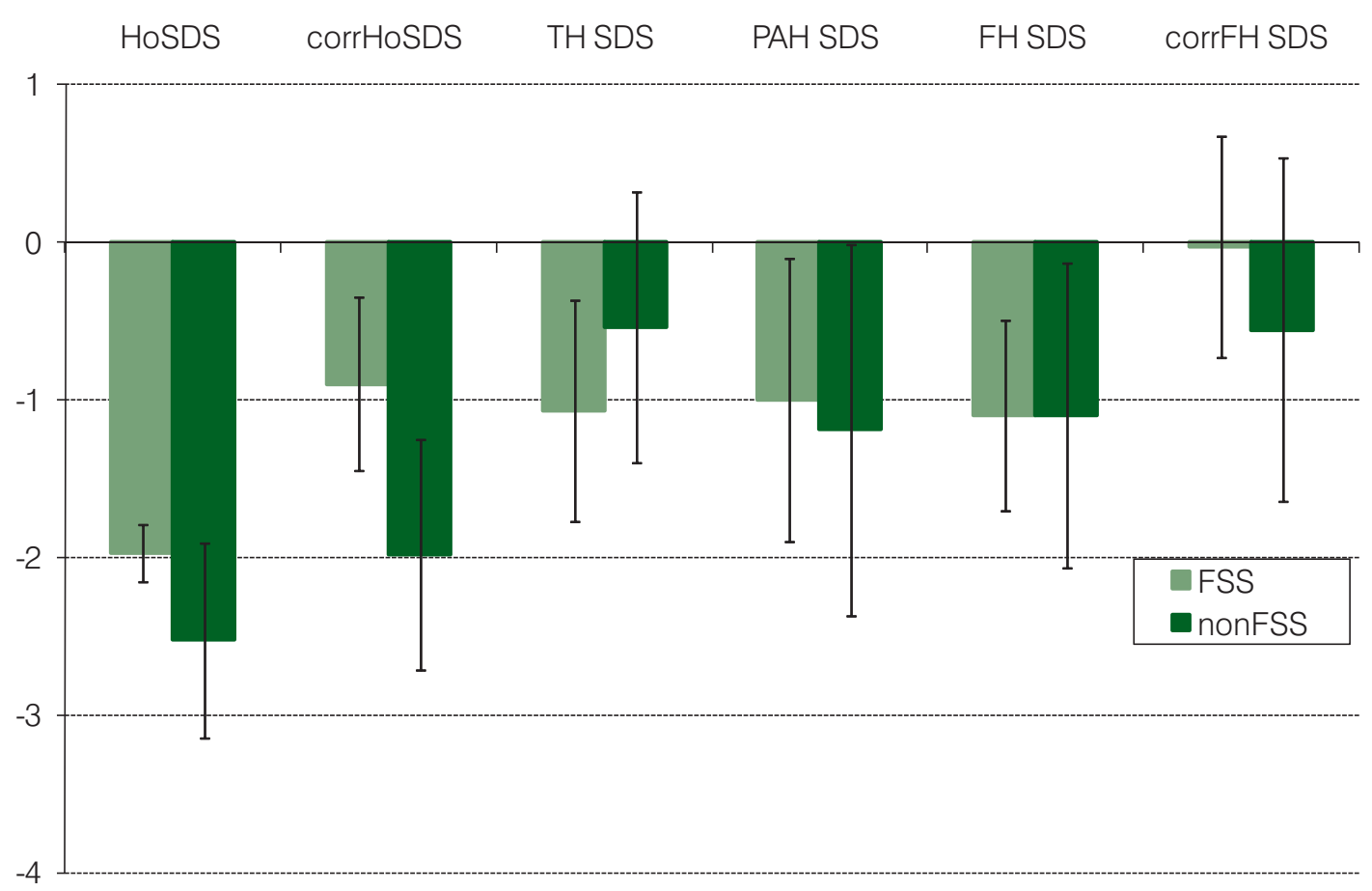

Fig. 1. Effectiveness of GH therapy in the patients, fulfilling the auxological criteria of FSS and nonFSS

Ryc. 1. Skuteczność terapii GH u pacjentów spetniających kryteria auksologiczne FSS i nonFSS

Table III. Selected auxological and hormonal data of patients fulfilling the auxological criteria of FSS and nonFSS before treatmrnt, obtained at rhGH therapy onset and at the attainment of FH

Tabela III. Wybrane dane auksologiczne i wyniki badań hormonalnych przed rozpoczęciem terapii GH i po uzyskaniu FH u dzieci spełniających przed leczeniem kryteria auksologiczne FSS i nonFSS

\begin{tabular}{|l|c|c|c|}
\hline \multicolumn{2}{|c|}{ FSS } & nonFSS & p \\
\hline Before treatment (at therapy onset) & 59 & 91 & \\
№ of patients & $11.8 \pm 2.6$ & $12.4 \pm 3.2$ & 0.04 \\
Age (years) & $-1.97 \pm 0.18$ & $-2.52 \pm 0.62$ & $<0.0001$ \\
H $_{0}$ SDS & $-1.07 \pm 0.70$ & $-0.54 \pm 0.86$ & 0.07 \\
TH SDS & $-0.90 \pm 0.55$ & $-1.98 \pm 0.73$ & $<0.0001$ \\
corrH ${ }_{0}$ SDS & $-1.00 \pm 0.90$ & $-1.19 \pm 1.18$ & 0.24 \\
PAH SDS & $7.4 \pm 4.3$ & $7.7 \pm 4.1$ & 0.98 \\
GH peak (ng/mL) & $-0.38 \pm 1.40$ & $-0.49 \pm 1.49$ & 0.54 \\
IGF-I SDS & & & 0.32 \\
After treatment (at the attainment of FH) & $5.0 \pm 2.4$ & $4.7 \pm 3.2$ & 0.13 \\
Therapy duration (years) & $-1.10 \pm 0.60$ & $-1.10 \pm 0.96$ & $<0.01$ \\
\hline FH SDS & $-0.03 \pm 0.70$ & $-0.56 \pm 1.09$ & $<0.0001$ \\
\hline corrFH SDS & $0.87 \pm 0.54$ & $1.43 \pm 0.87$ & 0.57 \\
\hline FHSDS vs $H_{0} S D S$ & $0.20 \pm 0.95$ & $0.09 \pm 0.97$ & \\
\hline FHSDS vs PAH SDS & & & \\
\hline
\end{tabular}


Table IV. Selected auxological and hormonal data of the patients with sGH, pGHD and verifGHD, obtained at rhGH therapy onset and at the attainment of FH

Tabela IV. Wybrane dane auksologiczne i wyniki badań hormonalnych przed rozpoczęciem terapii GH i po uzyskaniu FH w zależności od ciężkości niedoboru GH przed rozpoczęciem leczenia

\begin{tabular}{|c|c|c|c|c|}
\hline & sGHD & pGHD & verifGHD & $\mathrm{p}$ \\
\hline \multicolumn{5}{|c|}{ Before treatment (at therapy onset) } \\
\hline № of patients & 22 & 106 & 22 & \\
\hline Age (years) & $11.7 \pm 3.4$ & $12.4 \pm 2.9$ & $11.6 \pm 3.0$ & 0.32 \\
\hline $\mathrm{H}_{0} \mathrm{SDS}$ & $-2.33 \pm 0.75$ & $-2.16 \pm 0.63$ & $-2.16 \pm 0.64$ & 0.66 \\
\hline TH SDS & $-0.74 \pm 0.82$ & $-0.61 \pm 0.81$ & $-0.62 \pm 0.80$ & 0.55 \\
\hline CorrH $_{0}$ SDS & $-1.59 \pm 0.87$ & $-1.56 \pm 0.91$ & $-1.54 \pm 0.96$ & 0.48 \\
\hline PAH SDS & $-1.11 \pm 1.21$ & $-1.06 \pm 1.11$ & $-1.36 \pm 0.74$ & 0.51 \\
\hline GH peak (ng/mL) & $3.2 \pm 1.5$ & $7.1 \pm 1.3$ & $14.7 \pm 4.5$ & $<0.0001$ \\
\hline IGF-I SDS & $-0.40 \pm 1.60$ & $-0.37 \pm 1.36$ & $-1.27 \pm 1.81$ & 0.03 \\
\hline \multicolumn{5}{|c|}{ After treatment (at the attainment of FH) } \\
\hline Therapy duration (years) & $5.4 \pm 3.2$ & $4.5 \pm 2.6$ & $6.0 \pm 3.8$ & 0.30 \\
\hline FH SDS & $-1.13 \pm 1.04$ & $-0.90 \pm 0.78$ & $-1.05 \pm 0.94$ & 0.71 \\
\hline corrFH SDS & $-0.39 \pm 1.01$ & $-0.30 \pm 0.94$ & $-0.51 \pm 1.20$ & 0.90 \\
\hline$\Delta$ FHSDS vs $\mathrm{H}_{0} \mathrm{SDS}$ & $1.24 \pm 1.07$ & $1.28 \pm 0.76$ & $1.11 \pm 0.70$ & 0.53 \\
\hline$\Delta$ FHSDS vs PAH SDS & $0.01 \pm 1.36$ & $0.13 \pm 0.91$ & $0.15 \pm 0.87$ & 0.93 \\
\hline
\end{tabular}

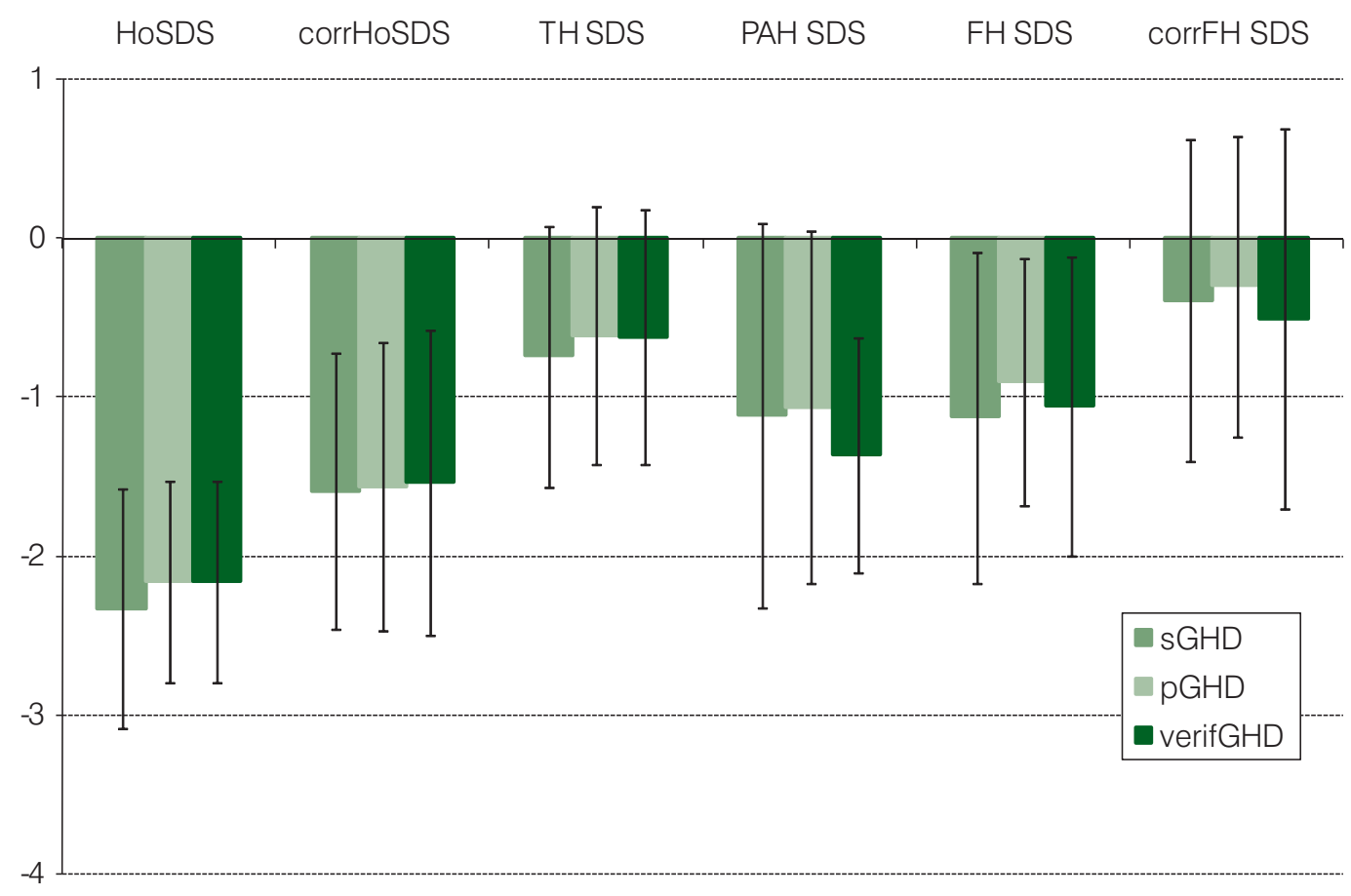

Fig. 2. Effectiveness of GH therapy with respect to the results of $\mathrm{GH}$ stimulating tests before treatment

Ryc. 2. Skuteczność terapii GH w zależności od wyników testów stymulacyjnych przed rozpoczęciem leczenia 
Table V. Selected data of the Groups of patients, depending on IGF-I SDS, obtained at rhGH therapy onset and at the attainment of $\mathrm{FH}$

Tabela V. Wybrane dane auksologiczne i wyniki badań hormonalnych przed rozpoczęciem terapii GH i po uzyskaniu FH w zależności od wydzielania IGF-I przed rozpoczęciem leczenia

\begin{tabular}{|c|c|c|c|}
\hline IGF-I SDS & Low & Normal & High \\
\hline \multicolumn{4}{|c|}{ Before treatment (at rhGH therapy onset) } \\
\hline № of patients & 39 & 98 & 13 \\
\hline Age (years) & $13.3 \pm 1.8$ & $12.1 \pm 2.9$ & $9.8 \pm 4.7$ \\
\hline $\mathrm{H}_{0} \mathrm{SDS}$ & $-2.26 \pm 0.58$ & $-2.19 \pm 0.63$ & $-2.43 \pm 0.47$ \\
\hline TH SDS & $-0.60 \pm 0.93^{\mathrm{a}}$ & $-0.56 \pm 0.74^{b}$ & $-1.24 \pm 0.73^{\mathrm{a}, \mathrm{b}}$ \\
\hline $\mathrm{CorrH}_{0} \mathrm{SDS}$ & $-1.68 \pm 1.05$ & $-1.65 \pm 0.84$ & $-1.19 \pm 0.80$ \\
\hline PAH SDS & $-1.13 \pm 1.06$ & $-1.10 \pm 1.11$ & $-1.10 \pm 0.90$ \\
\hline GH peak (ng/mL) & $9.1 \pm 5.6$ & $7.0 \pm 2.8$ & $7.7 \pm 3.0$ \\
\hline IGF-I SDS & $-2.47 \pm 0.98$ & $-0.04 \pm 0.67$ & $1.91 \pm 0.49$ \\
\hline \multicolumn{4}{|c|}{ After treatment (at the attainment of $\mathrm{FH}$ ) } \\
\hline Therapy duration (years) & $4.4 \pm 2.6^{c}$ & $4.8 \pm 2.8$ & $6.1 \pm 3.7^{c}$ \\
\hline FH SDS & $-0.90 \pm 0.90^{\mathrm{d}}$ & $-0.86 \pm 0.80^{e}$ & $-1.72 \pm 0.70^{\mathrm{d}, e}$ \\
\hline corrFH SDS & $-0.37 \pm 1.11$ & $-0.32 \pm 0.97$ & $-0.47 \pm 0.84$ \\
\hline$\Delta$ FHSDS vs $\mathrm{H}_{0} \mathrm{SDS}$ & $1.36 \pm 0.67^{\dagger}$ & $1.30 \pm 0.82^{9}$ & $0.71 \pm 0.89^{f, g}$ \\
\hline$\triangle$ FHSDS vs PAH SDS & $0.02 \pm 1.10$ & $0.22 \pm 0.90^{\mathrm{h}}$ & $-0.53 \pm 1.05^{h}$ \\
\hline
\end{tabular}

Significant differences: a, c, g, h $-\mathrm{p}<0.05 ; \mathrm{b}, \mathrm{d}, \mathrm{f}-\mathrm{p}<0.005$; e $-\mathrm{p}<0.001$

similar values of $\mathrm{H}_{0} \mathrm{SDS}$, children with high IGF-I levels had significantly lower TH and - consistently - significantly less severe deficit of height with respect to TH (expressed as corrH $\mathrm{SDS}_{0}$ ). Moreover, despite the longest therapy duration, in the Group of patients with high IGF-I secretion, the improvement of $\mathrm{FH}$ with respect to $\mathrm{H}_{0} \mathrm{SDS}$ was significantly worse and the obtained FH was significantly lower than in other Groups. Interestingly, in the patients with high IGF-I secretion before treatment, $\mathrm{FH}$ was significantly lower than PAH. Thus, in that group of patients, GH therapy did not improve the obtained FH with respect to the prognosis, calculated at therapy onset. The detailed data are presented in the Table V.

\section{Discussion}

The large studies on FH of the patients with isolated GHD, treated with GH up to the completion of linear growing were conducted - among others
- by Reiter et al. [15] and Carel et al. [16]. In the former of these studies, the patients' FH SDS was -0.8 for males and -1.0 for females, with a high correlation between prepubertal height gain and total height gain, confirming the importance of early start of the therapy [15]. In our study, the attained FH SDS presented slightly worse both for boys (-0.89) and for girls (-1.17), despite very similar TH SDS, less severe initial deficit of height and similar GH dose, probably due to about one year older age of our patients at therapy onset. Reiter et al. [15] have also pointed at the variability in responsiveness to treatment, related to individual GH sensitivity. The authors quoted the data on the variability of GHinduced IGF-I and IGFBP-3 synthesis, however that issue was not a subject of their analysis. Carel et al. [16] reported the mean FH SDS of treated patients on the level of -1.6, i.e. 0.4 SD below TH and the mean height gain on the level of 1.0 SD. The effectiveness of GH therapy, documented in their paper, presented worse than in our study, pos- 
sibly due to the more restrictive criteria of therapy discontinuation. Very recently, Kirk [17] has published the review concerning the indications to $\mathrm{GH}$ therapy in children, presenting the data on the mean FH ranging from $-0.9 \mathrm{SD}$ to -0.4 in uncontrolled studies, with no difference between the patients with isolated GHD and multiple pituitary hormone deficiencies.

In our study, auxological parameters turned out once again to be the most important factors, determining the effectiveness of GH therapy. Namely, in children with more severe deficit of height with respect to TH (nonFSS Group), the height gain during GH therapy was significantly better than in FSS Group, independently from similar GH and IGF-I levels in both Groups. Our observations are quite consistent with the results of other studies $[18,19]$.

In mathematical models of growth prediction, $\mathrm{GH}$ dose has been reported as one of the variables that may influence $\mathrm{FH}$, however of a moderate role [20]. In 2008, Coelho et al. [21] reported that, in GH-deficient children, higher GH doses, administered during puberty, did not improve FH. Our patients were treated with the relatively stable dose of $\mathrm{GH}(0.19 \pm 0.06 \mathrm{mg} / \mathrm{kg} /$ week $)$, thus that issue was not a matter of present study. In the study of Rachimiel et al. [18], almost the same GH dose $(0.18 \mathrm{mg} / \mathrm{kg} /$ week $)$ was administered and most of the patients reached $\mathrm{FH}$ within normal range, with an average FH close to -0.5 SD below midparental
HSDS. Similar results were also presented by Korpal-Szczyrska et al. in 2006 [22]. In our present study, the mean FH of the patients was also about -0.4 SD below TH, however with significant difference between the group of children with FSS (who reached $\mathrm{TH}$ ) and ones with nonFSS (who reached FH significantly below TH). The observation that only children with FSS (as a group) but not those with nonFSS have reached FH close to their genetically determined $\mathrm{TH}$ seems very important, as normal FH with respect to parental height is often considered a marker of good effectiveness of GH therapy. It seems possible that - in case of nonFSS - the factors disturbing growing (including GHD) could have so strong effect that the deficit of height may be to some extend irreversible during $\mathrm{GH}$ therapy.

Although the diagnosis of GHD is based on the results of GHST, it is well documented that GH therapy may be effective in the patients with normal results of GHST. In 2005, Loche et al. [23] stated that non-GH-deficient children may benefit from GH therapy, however, the predictors of the therapy responsiveness should be a subject of further clinical studies. In our study, a group of patient with the diagnosis of verifGHD presented - in fact - with constantly decreased IGF-I secretion and inconstant results of GHST. The effectiveness of GH therapy was similar in all the patients with "true" GHD and in ones with divergent results of GHST in two as-

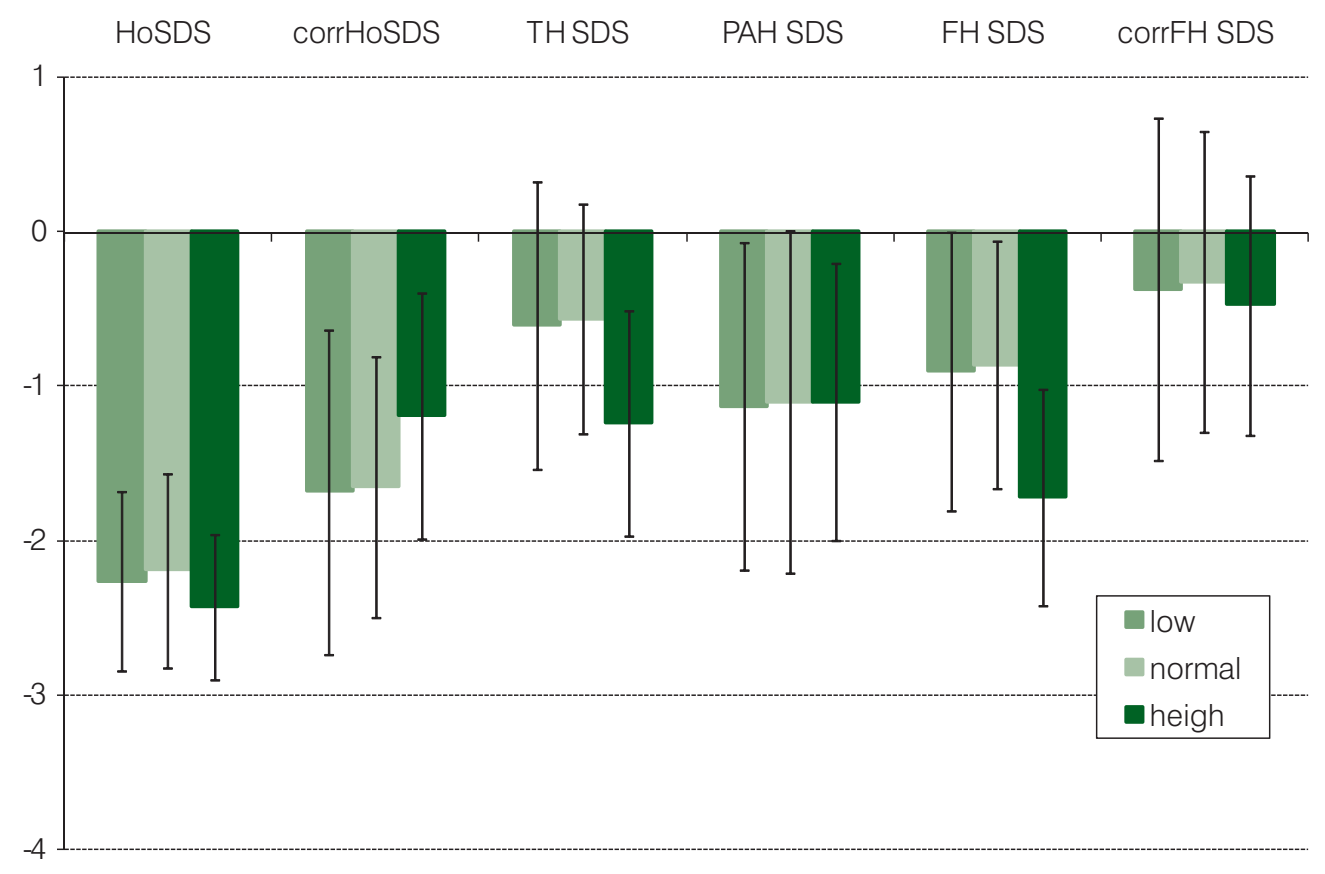

Fig. 3. Effectiveness of GH therapy in the patients with respect to IGF-I secretion before treatment Ryc. 3. Skuteczność terapii GH w zależności od wydzielania IGF-I przed rozpoczęciem leczenia 
sessments (thus not necessarily with GHD). Our results speak for the potential effectiveness of $\mathrm{GH}$ therapy in the patients with IGF-I deficiency despite normal results of GHST (obviously, GH insensitivity should be excluded in each case).

The significance of IGF-I assessment in prognosing GH therapy effectiveness has been a matter of discussion, being included as an important parameter in some models of growth prediction in terms of GH administration [24], while passed over in others [1].

The next important observation was related to the group of patients with high IGF-I secretion before treatment (thus with no secondary IGF-I deficiency), who had the lowest TH SDS. The improvement of FH SDS vs. $\mathrm{H}_{0} \mathrm{SDS}$ in that group was relatively poor. Moreover, it was the only group in which FH SDS was much lower than PAH SDS, calculated before treatment. It seems that in case of high IGF-I secretion despite low GH peak in GHST, the falsely positive results of GHST should be taken into account and further diagnostics seems necessary before qualifying such patients as GHdeficient. Our previous study pointed at the relatively high theoretical incidence of decreased GH peak in GHST in non-GH-deficient children [25]. Recently, in the classification of IGF-I deficiency, presented by Savage et al. [9], GHD was placed as a form of secondary IGF-I deficiency, thus - in practice - excluding that diagnosis in case of high or normal IGF-I secretion. It should be recalled that our patients were qualified to GH therapy independently from IGF-I levels, according to the rules of therapeutic program. The authors of current study are convinced that in case of elevated IGF-I concentration, the diagnosis of GHD is highly unlikely and further studies, including genetic assessment, should be considered.
The data concerning the relationships between the increase of IGF-I (and IGFBP-3) and improvement of $\mathrm{HV}$ are not consistent. According to Kriström et al. [26] $58 \%$ of the variation in the $1^{\text {st }}$ year growth response to GH therapy might be explained by serum levels of IGF-I and IGFBP-3 before treatment, and their increase during GH therapy. Conversely, Tillmann et al. [27], as well as Lanes and Jakubowicz [28] did not confirm any relationship between HV during GH therapy and IGF-I and IGFBP-3 concentrations. In 2005, Ranke et al. [29] reported a negative correlation between $\mathrm{HV}$ in the initial phase of GH treatment and IGF-I SDS before GH therapy, however with no correlation between HV during the therapy and the increase of IGF-I secretion. In 2009, Spilotis et al. [30] published the data that IGF-I increase during generation test might be an indirect indicator of GH secretory status. On the other hand, in the study of Cole et al. [31], 10 factors including auxological data and $\mathrm{GH}$ secretion explained only $42 \%$ of the variance of the $1^{\text {st }}$ year growth response to GH therapy. In that study, unfortunately, IGF-I secretion was not assessed. In present study, the severity of the deficit of height, as well as the severity of IGF-I deficiency but not the severity of GHD (exactly: not the results of GHST) turned out to be important prognostic factors of GH therapy effectiveness in children with isolated, non-acquired GHD.

Finally, it seems worth mentioning that in 2010 Takeda et al. [32] published the review of 34 publications, concerning the results of randomized controlled trials on GH therapy effectiveness. The authors pointed at the fact that most of the analyzed studies was relatively short-term and poorly documented, thus suggesting a strong need for further studies reporting near-FH or FH of GH treated patients. It seems that our paper may to some extent contribute to the achievement of that purpose. 


\section{REFERENCES/PIŚMIENNICTWO}

[1] Ranke M.B.: Clinical considerations in using growth hormone therapy in growth hormone deficiency. Endocr. Dev., 2010:18, 83-91.

[2] Rosenfeld R.G., Albertsson-Wikland K., Cassorla F. et al.: Diagnostic controversy: the diagnosis of childhood growth hormone deficiency revisited. J. Clin. Endocrinol. Metab., 1995:80, 1532-1540.

[3] Shalet S.M., Toogood A., Rahim A. et al. The diagnosis of growth hormone deficiency in children and adults. Endocrine Rev., 1998:19, 203-223.

[4] Rasat R., Livesey J.L., Espiner E.A. et al.: IGF-1 and IGFBP-3 screening for disorders of growth hormone secretion. N. Z. Med. J., 1996:109,156-159.

[5] GH Research Society: Consensus guidelines for the diagnosis and treatment of growth hormone deficiency in childhood and adolescence: summary statement of the GH Research Society. J. Clin. Endocrinol. Metab., 2000:85, 3990-3993.

[6] Federico G., Street M.E., Maghnie M. et al.: Assessment of serum IGF-I concentrations in the diagnosis of isolated childhood-onset GH deficiency: a proposal of the Italian Society for Pediatric Endocrinology and Diabetes (SIEDP/ISPED). J. Endocrinol. Invest., 2006:29, 732-737.

[7] Lemaire P., Brauner N., Hammer P. et al.: Improved screening for growth hormone deficiency using logical analysis data. Med. Sci. Monit., 2009:15, MT5-10.

[8] Wit J., Ranke MB., Kelnar C.J.H.: ESPE classification of pediatric endocrine diagnoses. Short stature. Horm. Res., 2007:68, 1-9.

[9] Savage M.O., Burren C.P., Rosenfeld R.G.: The continuum of growth hormone-IGF-I axis defects causing short stature: diagnostical and therapeutical challenges. Clin. Endocrinol., 2010:72, 721-728.

[10] Romer T.E., Walczak M., Wiśniewski A. et al.: Children with growth disorders qualified in Poland for growth hormone therapy. Pediatria Praktyczna, 2001:9, 41-54 (in Polish).

[11] Palczewska I., Niedźwiecka Z.: Indices of somatic development of children and adolescents in Warsaw. Medycyna Wieku Rozwojowego, 2001:5 (Suppl 1 to № 2), 17-118 (in Polish).

[12] Ranke M.B.: Towards a consensus on the definition of idiopathic short stature. Horm. Res., 1996:45 (Suppl 2), 64-66.

[13] Greulich W.W., Pyle S.I.: Radiographic Atlas of Skeletal Development of the Hand and Wrist. Stanford University Press, Stanford, California, 1993.

[14] Bayley N., Pinneau S.R.: Tables for predicting adult height from skeletal age: revised for use with the Greulich-Pyle hand standards. J. Pediatr., 1952:40, 423-441.

[15] Reiter E.O., Price D.A., Witton P. et al.: Effect of growth hormone (GH) treatment on the near-final height of 1258 patients with idiopathic GH deficiency: analysis of a large international database. J. Clin. Endocrinol. Metab., 2006:91, 2047-2054.

[16] Carel J.C., Ecosse E., Nicolino M. et al.: Adult height after long term treatment with recombinant growth hormone for idiopathic isolated growth hormone deficiency: observational follow up study of the French population based registry. B.M.J., 2002:25, 70.

[17] Kirk J. Indications for growth hormone therapy in children. Arch. Dis. Child., 2012:97, 63-68.

[18] Rachmiel M., Rota V., Atenafu E. et al.: Final height in children with idiopathic growth hormone deficiency treated with a fixed dose of recombinant growth hormone. Horm. Res., 2007:68, 236-243.

[19] Westphal 0., Lindberg A.; Swedish KIGS National Board. Final height in Swedish children with idiopathic growth hormone deficiency enrolled in KIGS treated optimally with growth hormone. Acta Paediatr., 2008:97, 1698-1706.

[20] Ranke M.B., Lindberg A., Martin D.D. et al. The mathematical model for total pubertal growth in idiopathic growth hormone (GH) deficiency suggests a moderate role of GH dose. J. Clin. Endocrinol. Metab., 2003:88, 4748-4753.

[21] Coelho R., Brook C.G., Preece M.A. et al.: A randomised study of two doses of biosynthetic human growth hormone on final height of pubertal children with growth hormone deficiency. Horm. Res., 2008:70, 85-88.

[22] Korpal-Szczyrska M, Dorant B, Kamińska H. et al.: [Evaluation of final height in patients with pituitary growth hormone deficiency who were treated with growth hormone replacement]. Endokrynol. Diabetol. Chor. Przemiany Materii Wieku Rozw., 2006:12 (1), 31-34 (in Polish).

[23] Loche S., Casini M.R., Ubertini G.M. et al.: Growth hormone treatment in non-growth hormone-deficient short children. J. Endocrinol. Invest., 2005:28, 193-198.

[24] Valle D., Bartolotta E., Caruso M. et al.: Prediction of response to growth hormone treatment in pre-pubertal children with growth hormone deficiency. J. Endocrinol. Invest., 2011:34, 126-130.

[25] Hilczer M., Smyczyńska J., Lewiński A.: Limitations of clinical utility of growth hormone stimulating tests in diagnosing children with short stature. Endocrine Regul., 2006:40, 69-75.

[26] Kriström B., Jansson C., Rosberg S. et al.: Growth response to growth hormone (GH) treatment relates to serum insulin-like growth factor I (IGF-I) and IGF binding protein-3 in short children with various GH secretion capacities: Swedish Study Group for Growth Hormone Treatment. J. Clin. Endocrinol. Metab., 1997:82, 2889-2898.

[27] Tillmann V., Patel L,. Gill M.S. et al.: Monitoring serum insulin-like growth factor-I (IGF-I), IGF binding protein-3 (IGFBP-3), IGF-I/IGFBP-3 molar ratio and leptin during growth hormone treatment for disordered growth. Clin. Endocrinol., 2000:53, 329-336. 
[28] Lanes R., Jakubowicz S.: Is insulin-like growth factor-1 monitoring useful in assessing the response to growth hormone of growth hormone-deficient children? J. Pediatr., 2002: 141,606-610.

[29] Ranke M.B., Traunecker R., Martin D.D. et al.: IGF-I and IGF binding protein-3 levels during initial GH dosage step-up are indicators of GH sensitivity in GH-deficient children and short children born small for gestational age. Horm. Res., 2005:64, 68-76.

[30] Spiliotis B.E., Alexandrides T.K., Karystianos C. et al.: The insulin-like growth factor-I (IGF-I) generation test as an indicator of growth hormone status. Hormones, 2009:8, 117-128.

[31] Cole T.J., Hindmarsh P.C., Dunger D.B.: Growth hormone (GH) provocation tests and the response to GH treatment in GH deficiency. Arch. Dis. Child., 2004:89, 1024-1027.

[32] Takeda A., Cooper K., Bird A. et al.: Recombinant human growth hormone for the treatment of growth disorders in children: a systematic review and economic evaluation. Health Technol. Assess., 2010:14, 1-209. 